\title{
Efficacy of Garlic Tablet to Control Seed-Borne Fungal Pathogens of Cucumber
}

\author{
A. B. M. RUHUl AMIN ${ }^{1}$, M. M. RASHID ${ }^{2 *} \&$ M. B. MEAH $^{3}$ \\ ${ }^{1}$ Rupali Bank Ltd., Bangladesh \\ ${ }^{2}$ Bangladesh Rice Research Institute, Regional Station, Sonagazi, Feni, Bangladesh \\ ${ }^{3}$ Plant Pathology Division, Bangladesh Agricultural University, Mymensingh-2202, Bangladesh
}

\begin{abstract}
An experiment was conducted to find out the efficacy of garlic tablets in controlling seed-borne fungal pathogens of cucumber. Suspention of garlic tablet was prepared in water at the concentrations of 1:3, 1:4, 1:5 and 1:6. Seeds of cucumber were treated with the suspentions for 15 minutes. Seeds under control were treated with plain water. Seven fungal pathogens, namely Aspergillus flavus, Aspergillus niger, Fusarium oxysporum, Fusarium moniliforme, Penicillium spp., Doratomycetes $s p$. and Rhizopus stolonifer were found to be associated with the cucumber seeds. Their prevalence ranged from 1.0-8.0, 1.0-4.0, 1.0-15.0, 1.0-8.0, 0.0-9.0, 1.0-17.0 and 0.0-12.0\% respectively under different treatments including control. All concentrations of the material caused significant decrease in the prevalence of seed-bornefungi, occurrence of abnormal seedlings and rotten seeds as compared to control. On the other hand, germination increased over control due to seed treatment with garlic tablet. The higher increase in germination and reduction in occurrence of seed-borne fungi, rotten seed and abnormal seedling were corroborated with higher doses of garlic tablet.
\end{abstract}

Key words: Garlic tablet, cucumber seed, seed treatment, fungal pathogens, control.

\section{INTRODUCTION}

Cucumber (Cucumis sativus L.) is a common vegetable in Bangladesh. It has high nutritive values and contains carbohydrates, protein, fats, vitamins and minerals (Bose and Som, 1986). Cucumber suffers from many diseases. Some of them are seed borne (Richardson, 1973; Ahmad and Sultana, 1983; Anon., 2004). Seed treatment with different botanicals including garlic extract has been tested and found effective alternative approaches to combat the seed-borne diseases of many crops including cucumber (Alice and Rao, 1987; Kurucheve and Padmavathi, 1997; Rahman et al., 1997; Islam et al., 2001, Anon., 2004; Nasum et al., 2009). Reports on the efficacy of garlic extract and garlic tablet for seed treatment against seed-borne fungi and to increase yield of different crops are available in Bangladesh (Islam et al., 2001; Asad-ud-doullah, 2002; Masum et al., 2009). Islam et al., (2001) reported that treatment of jute seed with garlic extract (1:2) gave reduction in the prevalence of Colletotrichum corchori, Macrophomina phaseolina, Botryodiplodia theobromae, Fusarium spp., Penicillium spp., Aspergillus niger and A. flavus and increase germination and yield of jute fiber appreciably. Under field conditions seed treatment with garlic extract increased seed yield of jute over farmer's saved seed. Treatment of rice seeds with garlic

*Corresponding author: SO, BRRI, Regional Station, Sonagazi, Feni, Mobile: 01712887507, E-mail: mirza_26658@yahoo.com

(C) 2009 School of Agriculture and Rural Development, Bangladesh Open University, All rights reserved. 
was found to be effective to decrease seedling diseases viz. brown spot, blast, bakanae, foot rot and seedling blight (Asad-ud-doullah, 2002). Recently, Masum et al. (2009) reported that treatment of sorghum seed with garlic tablet, formulated by Integrated Pest Management (IPM) Laboratory, Bangladesh Agricultural University, Mymensingh caused significant reduction in seed-fungi. Increased germination higher than the national standard (>80.0\%) was also obtained with the treatment. Reports on the effectiveness of garlic to control seed-borne fungi and to increase quality of seed cucumber are not available in the country.

In view of the above facts the present investigation was conducted to find out the effect of garlic tablet on the prevalence of seed-borne fungi and germination of cucumber seeds.

\section{MATERIALS ANd Methods}

Garlic tablets were obtained from Integrated Pest Management (IPM) laboratory, Bangladesh Agricultural University (BAU), Mymensingh. The tablets were formulated by the same laboratory. They were prepared from paste of fresh garlic cloves. For seed treatment, suspension of the tablets was prepared in distilled water at the concentrations of 1:3, 1:4, 1:5 and 1:6. For each concentration, required quantity of the tablet and water were taken in a $250 \mathrm{ml}$ conical flask and thoroughly mixed by manual shaking. Each concentration of the tablet represented a treatment. Cucumber seeds were collected from a seed store of Mymensingh town. One hundred seeds were randomly selected from the seed sample and taken in each conical flask containing garlic tablet suspension. The seeds were treated with the suspension for 15 minutes with frequent shaking with hands. Another 100 seeds were treated with plain distilled water for the same duration, which represented the control. The treated seeds were air dried and plated on 2-ply filter paper (Whatman No. 2) following standard methods according to International Rules for Seed Testing (Anon., 2000) as recommended by International Seed testing Association (ISTA). Before plating the filter paper and the petridishes were sterilized in an autoclave. Ten treated seeds were plated in each petridish and ten petridishes (replications) were used for each treatment (concentration). The petridishes were incubated at room temperature $\left(25 \pm 2^{\circ} \mathrm{C}\right)$ for one week.

At the end of incubation period, prevalence of fungi associated with the seeds was recorded. Data on germinated seeds, and occurrence of rotten seeds, abnormal seedling and seeds yielded seed-borne fungi were also recorded. All data were expressed in percentage based on total number of seeds plated.

Collected data were analyzed for ANOVA following Completely Randomized Design (CRD) using MSTAT-C computer program. Differences in means of different treatments were evaluated for significance following Duncan's Multiple Range Test (Gomez and Gomez, 1984).

\section{Results AND Discussion}

\section{Fungi associated with cucumber seeds}

Seven fungi were found to be associated with cucumber seeds. In order of prevalence, they were Rhizopus stolonifer, Fusarium oxysporum, Doratomycetes sp., Fusarium moniliforme, Penicillium spp., Aspergillus niger and Aspergillus flavus. Their prevalence ranged from 1.0-8.0, 1.0-4.0, 1.015.0, 1.0-8.0, 0.0-9.0, 1.0-17.0 and 0.0-12.0\% respectively under five treatments including control. The highest prevalence of all fungi, except $A$. flavus, was found under control. Their prevalence was significantly reduced due to treatment of seeds with the material all concentration over control. The highest reduction of their prevalence was obtained with the concentration of 1:3, which was followed by 1:4 and 1:5. The least effective concentration to reduce fungal prevalence was 1:6. The prevalence fungi were completely eliminated at 1:3 in case of Penicillium and at 1:3 and 1:4 in case of Doratomycetes. Prevalence of A. flavus was significantly reduced over control at 1:5 and higher concentration. Its population increased over control at the concentration of 1:6 (Table 1). 
Table 1. Effect of seed treatment with garlic tablet on the prevalence of seed-borne fungi of cucumber

\begin{tabular}{|c|c|c|c|c|c|c|c|}
\hline \multirow{2}{*}{$\begin{array}{l}\text { Concentration of } \\
\text { garlic tablet } \\
\text { (Garlic:water) }\end{array}$} & \multicolumn{7}{|c|}{ \% Seed-borne infection } \\
\hline & $\begin{array}{c}\text { Aspergillus } \\
\text { niger }\end{array}$ & $\begin{array}{l}\text { Aspergillus } \\
\text { flavus }\end{array}$ & $\begin{array}{c}\text { Fusarium } \\
\text { moniliforme }\end{array}$ & $\begin{array}{c}\text { Fusarium } \\
\text { oxysporum }\end{array}$ & Penicillium sp. & $\begin{array}{l}\text { Rhizopus } \\
\text { stolonifer }\end{array}$ & Doratomycetes sp. \\
\hline $1: 3$ & $1.0 \mathrm{e}$ & $1.0 \mathrm{~d}$ & $1.0 \mathrm{e}$ & $1.0 \mathrm{~d}$ & $0.0 \mathrm{e}$ & $1.0 \mathrm{e}$ & $0.0 \mathrm{~d}$ \\
\hline $1: 4$ & $2.0 \mathrm{~d}$ & $1.0 \mathrm{~d}$ & $1.0 \mathrm{~d}$ & $3.0 \mathrm{~d}$ & $1.0 \mathrm{~d}$ & $2.0 \mathrm{~d}$ & $0.0 \mathrm{~d}$ \\
\hline $1: 5$ & $5.0 \mathrm{c}$ & $2.0 \mathrm{c}$ & $2.0 \mathrm{c}$ & $5.0 \mathrm{c}$ & $4.0 \mathrm{c}$ & $8.0 \mathrm{c}$ & $3.0 \mathrm{c}$ \\
\hline $1: 6$ & $7.0 \mathrm{~b}$ & $5.0 \mathrm{a}$ & $5.0 \mathrm{~b}$ & $9.0 \mathrm{~b}$ & $7.0 \mathrm{~b}$ & $10.0 \mathrm{~b}$ & $5.0 \mathrm{~b}$ \\
\hline Control (Water only) & $8.0 \mathrm{a}$ & $4.0 \mathrm{~b}$ & $8.0 \mathrm{a}$ & $15.0 \mathrm{a}$ & $9.0 \mathrm{a}$ & $17.0 \mathrm{a}$ & $12.0 \mathrm{a}$ \\
\hline
\end{tabular}

Values within the same common with a common letter (s) do not differ significantly $(P=0.05)$.

Data were analyzed after transformation.

\section{Germination and occurrence of rotten seeds}

Germination of cucumber seeds ranged $67.0-80.0 \%$ under different treatments. Treatment of cucumber seeds with garlic tablet caused significant increase in germination at 1:5 and higher concentration as compared to control (Table 2).

Maximum of $32.0 \%$ rotten seeds were observed when seeds were not treated with the garlic tablet. The occurrence of rotten seeds was reduced to 2.0, 7.0, 11.0 and $22.0 \%$ due to seed treatment with the material at 1:3, 1:4, 1:5 and 1:6 concentrations. The reduction was significant over control at all concentrations (Table 2 ).

Table 2. Effect of different concentration of suspension with garlic tablet on the quality of cucumber seeds

\begin{tabular}{ccccc}
\hline $\begin{array}{c}\text { Concentration } \\
\text { (Garlic:water) }\end{array}$ & $\begin{array}{c}\text { Germinated } \\
\text { seed (\%) }\end{array}$ & $\begin{array}{c}\text { Rotten seed } \\
(\%)\end{array}$ & $\begin{array}{c}\text { \% Seed yielded } \\
\text { fungi }\end{array}$ & $\begin{array}{c}\text { Abnormal } \\
\text { seedling (\%) }\end{array}$ \\
\hline $1: 3$ & $80.0 \mathrm{a}$ & $2.0 \mathrm{e}$ & $5.0 \mathrm{e}$ & $6.0 \mathrm{~d}$ \\
$1: 4$ & $75.0 \mathrm{~b}$ & $7.0 \mathrm{~d}$ & $10.0 \mathrm{~d}$ & $8.0 \mathrm{c}$ \\
$1: 5$ & $73.0 \mathrm{~b}$ & $11.0 \mathrm{c}$ & $29.0 \mathrm{c}$ & $14.0 \mathrm{~b}$ \\
$1: 6$ & $68.0 \mathrm{c}$ & $22.0 \mathrm{~b}$ & $47.0 \mathrm{~b}$ & $15.0 \mathrm{a}$ \\
\hline Control (Water only) & $67.0 \mathrm{c}$ & $32.0 \mathrm{a}$ & $73.0 \mathrm{a}$ & $15.0 \mathrm{a}$ \\
\hline
\end{tabular}

Values within the same common with a common letter (s) do not differ significantly $(P=0.05)$.

Data were analyzed after transformation.

\section{Occurrence of abnormal seedling}

The highest occurrence of $15.0 \%$ abnormal seedling was recorded when seeds were not treated (control) or treated with the garlic tablet at 1:6 concentration. Other treatments gave significant reduction in abnormal seedlings over control. The lowest was of $6.0 \%$ abnormal seedling was obtained with the concentration of 1:3, which was followed by 1:4 and 1:5 (Table 2).

\section{Percentage of seed yielded fungi}

Fungi grew from $73.0 \%$ of cucumber seeds on petridishes when seed were not treated (control). It was reduced to $5.0,10.0,29.0$ and $47.0 \%$ due to seed treatment with garlic tablet at 1:3, 1:4, 1:5 and 1:6, respectively. The reduction was significant at all concentration as compared to control. The differences in effectiveness at various concentrations were also significant (Table 2).

Results of the present investigation reveal that at least seven seed-borne fungal pathogens namely Aspergillus niger, Aspergillus flavus, Fusarium oxysporum, Fusarium moniliforme, Penicillium spp., Rhizopus stolonifer and Doratomycetes sp. are associated with cucumber seeds in Bangladesh. Other investigators also found association of similar fungi with cucumber seeds (Braccini and Dhingra, 1996; Pushpa, 1999; Begum and Momin, 2000). Significant reduction of all fungi was achieved with the treatment of cucumber seeds with garlic tablet at 1:3 and 1:6 concentrations. Higher reduction was corroborated with the higher doses of garlic tablet. Seed treatment with the tablet not only reduced seed-borne fungal infection but also improved the 
germination, and decreased occurrence of rotten seeds and abnormal seedling significantly over control. The findings of the present investigation are in agreement with the findings of other investigators (Fakir and Khan, 1992; Islam et al., 2001; Asad-ud-doullah, 2002; Masum et al., 2009). Seed health test of jute (Corchorus capsularis L.) performed by Islam et al., (2001) revealed that untreated farmer's saved seed yielded all together 13 different fungi. Seed treatment with garlic extract (1:2) gave reduction in the prevalence of Colletotrichum corchori, Macrophomina phaseolina, Botryodiplodia theobromae, Fusarium spp., Penicillium spp., Aspergillus niger and A. flavus. Treatment of rice seeds with garlic was found to be effective to decreaseseedling diseases viz. brown spot, blast, bakanae, foot rot and seedling blight (Asad-ud-doullah, 2002). Recently, Masum et al. (2009) reported that treatment of sorghum seed with garlic tablet caused significant reduction in seed-borne fungi and increased germination.

\section{Literature Cited}

Ahmed, N. and Sultana, K. 1983. Fungitoxic effect of garlic on treatment of jute seed. Bangladesh J. Bot. 13(2), 130-136.

Alice, D. and Rao, A. V. 1987. Antifungal effects of plant extracts on Drechslera oryzae in rice. Int. Rice Res. Newsl. 12(2), 28.

Anonymous. 2000. International Seed Testing Association. Seed Sci. \& Tech. 21 (Supplement): 2529 and 141-160.

Anonymous. 2004. Garlic tablet, in plant disease control. A leaflet published by IPM Lab, Department of Plant Pathology. Bangladesh Agricultural University, Mymensingh, Bangladesh.

Asad-ud-doullah, A., Anam, M. K., Nazrul Islam, M., Rahman, M., Fakir, G. A. and Hossain. I. 2002. Effect of seed cleaning, washing and seed treatment on seedling disease incidence and yield of Rice. Pakistan Journal of Biological Sciences. 5(7), 767-769.

Begum, H. A. and Momin, A. 2000. Comparison between two detection techniques of seed-borne pathogen in cucurbits in Bangladesh. Pakistan Journal of Scientific and Industrial Res. 43(4), 244-248.

Bose, T. K., Kabir, J. and Som, T. K. 1986. Vegetables of India. Nayaprakash, Calcutta, India. 312-334 pp.

Braccini, A. L. and Dhingra, O. D. 1996. Identification of fungi associated with soybean and cucumber seeds by different detection methods. Department of Agronomy, University of Estadual de Maringa. 18(3), 495-503.

Fakir, G. A. and Khan, A. A. 1992. Control of some selected seed borne fungal pathogens of jute by seed treatment with garlic extract. Proc. BAU Res. Prog. 6, 176-180.

Gomez, K. A. and Gomez, A. A. 1984. "Statistical Procedures for Agricultural Research" (second Edn). John Wiley and Sons, New York, 680 pp.

Islam, S. M. A., Hossain, I., Fakir, G. A. and Asad-ud-doullah, M. 2001. Effect of physical seed sorting, seed treatment with garlic extract and vitavax 200 on seed borne fungal flora and seed yield of jute (Corchorus capsularis L.). Pakistan Journal of Biological Sciences. 4(12), 1509-1511.

Kurucheva, V. and R. Padmavathi. 1997. Effect of seed treatment with plant products on seed germination, growth and vigour of chilli seedlings (K-1). Indian phytopathol. 50(4), 529-530.

Masum, M. M. I., Islam, S. M. M. and Fakir, G. A. 2009. Effect of seed treatment practices in controlling seed-borne fungi in sorghum. Scientific Research and Essay 4(1), 2227.Available online at http://www.academicjournals.org/SRE

Pushpa, K., Borkar, G. M. and Patil, D. V. 1999. Studies on seed-borne pathogens of pumpkin, cucumber, watermelon and muskmelon. Journal of soils and crops. 9(2), 234-238.

Rahman, G. M. M., Islam, M. R. and Wadud, M. A. 1999. Seed treatment with plant extracts and hot water: a potential biophysical method of controlling seed-borne infection of wheat. Bangladesh Journal of Training and Development. 12(1-2), 185-190.

Richardson, M.S. 1973. An annotated list of seed-borne diseases. $3^{\text {rd }}$ Edn. 65-68 pp. 